\title{
Insulin Levels in the Umbilical Vein and in the Umbilical Artery of Newborns of Normal and Gestational Diabetic Mothers*
}

\author{
K. Thomas**, M. de Gasparo and J.J. Howt
}

Laboratoire de Recherches de la Clinique Médicale, Hôpital Saint-Pierre et département d'Obstétrique et Gynécologie, (Prof. J.A. SchookaterT), Université de Louvain, Belgique

Received October 12, 1966

Summary. Insulin levels (by double antibody radioimmunological assay) were studied in the venous blood of mothers at vaginal delivery and in the umbilical vein and artery of their newborns. - In 14 normal mothers the insulin levels after 10 hours fasting were 18.5 13.6 $\mu \mathrm{U} / \mathrm{ml}$ (mean \pm S.E.M.). In their newborns (mean : $3.420 \mathrm{~kg}$, all $<4.000 \mathrm{~kg}, 38-41$ weeks gestation) the insulin levels were low and similar in the umbilical vein $(5.6 \pm 0.7 \mu \mathrm{U} / \mathrm{ml})$ and in the umbilical artery $(6.6 \pm 0.7$ $\mu \mathrm{U} / \mathrm{ml})$. The plasma glucose levels in the mothers were $99.7+3.9 \mathrm{mg} / 100 \mathrm{ml}$ and in the umbilical vein $77.3 \pm 3.7$ $\mathrm{mg} / \overline{100} \mathrm{ml}$ and the umbilical artery $65.5 \pm 3.2 \mathrm{mg} / 100$ $\mathrm{ml}$. They were significantly different from each other. Eleven normal mothers receiving a glucose infusion (ca. $15 \mathrm{~g} / 3$ hours) during delivery had $42.0 \pm 9.9 \mu \mathrm{U} / \mathrm{ml}$ insulin in their venous blood. In their newborns with a normal birthweight (mean : $3.585 \mathrm{~kg}$, all $<4.000 \mathrm{~kg}$ ) the insulin levels were not increased either in the umbilical vein $(7.0 \pm 1.0 \mu \mathrm{U} / \mathrm{ml})$ or in the artery $(7.9 \pm 1.0 \mu \mathrm{U} / \mathrm{ml})$. The plasma glucose levels in the mothers were $128.0 \pm$ $7.7 \mathrm{mg} / 100 \mathrm{ml}$, and in the umbilical vein $105.0 \pm 7.5 \mathrm{mg} /$ $100 \mathrm{ml}$ and in the umbilical artery $88.8 \pm 8.6 \mathrm{mg} / 100 \mathrm{ml}$. The plasma glucose levels were significantly different from each other. - In six infants with "large birthweight" (>4.100 kg) born to untreated mothers with gestational diabetes the insulin levels were superior to the values found in normal newborns. In three of these infants, born to mothers who did not receive a glucose infusion, the insulin levels in the umbilical vein were 38 , 42 and $13 \mu \mathrm{U} / \mathrm{ml}$, and in the artery they were $17,34.5$ and 18.5 $\mu \mathrm{U} / \mathrm{ml}$. The other three mothers received a glucose infusion, their newborns had in the umbilical vein an insulin level of $15.5,65$ and $19 \mu \mathrm{U} / \mathrm{ml}$ and in the artery 20 , 72.5 and $14 \mu \mathrm{U} / \mathrm{ml}$. - In conclusion, the normal infant at birth has a low insulin level, which is equal in the umbilical vein and artery. In 6 heavy infants born to untreated latent diabetic mothers, the insulin levels were significantly higher than in normals, and the levels in the umbilical vein and the artery were different from one another. This latter data on hyperinsulinism is discussed in relation with hyperplasia of the islets of Langerhans observed in stillborn infants of mothers with insulindependant diabetes or gestational diabetes.

L'insulinémie dans l'artère et la veine ombilicales chez les nouveau-nés de mères normales et de mères atteintes de diabète de grossesse non traité.

Résumé. L'insuline dosée par la méthode radioimmunologique aux doubles anticorps est déterminée dans le sang veineux de la mère au moment de l'accouchement et dans la veine et l'artère ombilicales des nouveau-nés. L'insulinémie de 14 mères normales après 10 heures de

* This study was supported by grants from the Fondation Médicale Reine Elisabeth, the Fondation de la Recherche Scientifique Médicale, the Eli Lilly and Co., Indianapolis U.S.A., and the Cynamid International, Pearl River, N.Y., U.S.A.

** Aspirant du Fonds National de la Recherche Scientifique. jeûne est de $18.5 \pm 3.6 \mu \mathrm{U} / \mathrm{ml}$ (moyenne, écart-type de la moyenne). Les taux d'insuline dans le sang de leurs nouveau-nés (moyenne: $3.420 \mathrm{~kg}$; tous $<4.000 \mathrm{~kg}$; 38 à 41 semaines de grossesse) sont bas dans la veine $(5.6+0.7$ $\mu \mathrm{U} / \mathrm{ml})$ comme dans l'artère ombilicale $(6.6 \pm 0.7 \mu \mathrm{U} / \mathrm{ml})$. Les glycémies plasmatiques chez les mères sont $99.7 \pm 3.9$ $\mathrm{mg} / 100 \mathrm{ml}$ et dans la veine ombilicale $(77.3 \pm 3.7 \mathrm{mg} /$ $100 \mathrm{ml}$ ) et dans l'artère ombilicale $(65.5 \pm 3.2 \mathrm{mg} / 100 \mathrm{ml})$. Les glycémies des trois compartiments sont significativement différentes entre elles. - Onze mères normales qui ont reçu une perfusion glucosée ( $\pm 15 \mathrm{~g} / 3$ heures) pendant le travail, présentent au moment de l'accouchement une insulinémie qui s'élève à $42.0 \pm 9.9 \mu \mathrm{U} / \mathrm{ml}$. Leurs nouveau-nés, de poids normal à la naissance (moyenne: $3.585 \mathrm{~kg}$; tous $<4.000 \mathrm{~kg}$ ) n'ont pas d'augmentation de l'insulinémie ni dans la veine ombilicale $(7.0+1.0 \mu \mathrm{U} / \mathrm{ml})$ ni dans l'artère ombilicale $(7.9 \pm 1.0 \mu \mathrm{U} / \mathrm{ml})$. Les glycémies plasmatiques chez les mères sont $128.0+7.7 \mathrm{mg} / 100$ $\mathrm{ml}$ et dans la veine ombilicale $105.0 \pm 7.5 \mathrm{mg} / 100 \mathrm{ml}$ et dans l'artère ombilicale $88.8 \pm 8.6 \mathrm{mg} / 100 \mathrm{ml}$. Les glycémies des trois compartiments sont significativement différentes entre elles. - Chez 6 enfants de poids excessif $(>4.000 \mathrm{~kg}$ ) nés de mères atteintes de diabète de la gestation non traité, l'insulinémie est supérieure aux valeurs de nouveau-né normal. Trois de ces enfants, dont la mère n'a pas été perfusée, ont des taux d'insuline dans la veine ombilicale de 38,42 et $13 \mu \mathrm{U} / \mathrm{ml}$ et dans l'artère de $17,34.5$ et $18.5 \mu \mathrm{U} / \mathrm{ml}$. Les trois autres parturientes reçoivent une perfusion de glucose. L'insulinémie dans la veine ombilicale chez leurs nouveau-nés est respectivement de $15.5,65$ et $19 \mu \mathrm{U} / \mathrm{ml}$ et de $20,72.5$ et $14 \mu \mathrm{U} / \mathrm{ml}$ dans l'artère. - En conclusion, les enfants normaux à la naissance ont des taux d'insuline bas et identiques dans l'artère et la veine ombilicales. Chez les gros enfants de mères atteintes de diabète de gestation non traité, l'insulinémie est significativement plus élevée que chez les enfants normaux. Les valeurs trouvées dans la veine ombilicale sont différentes de celles de l'artère ombilicale. Cet hyperinsulinisme confirme les observations concernant l'hyperplasie des îlots de Langerhans observée chez les enfants mort-nés de mère diabétique ou atteinte de diabète de la gestation. Le parallélisme entre l'hyperinsulinémie foetale et le poids excessif à la naissance est souligné.

Blutinsulinspiegel in der Arteria und Vena Umbilicalis bei Neugeborenen gesunder Mütter und von Müttern mit unbehandeltem Schwangerschaftsdiabetes.

Zusammenfassung. Mit der radioimmunologischen Doppelantikörpermethode wurde der Insulinspiegel im Venenblut der Mutter im Augenblick der Geburt und in der Nabelschnurarterie und -vene des Neugeborenen be. stimmt. - Der Insulinspiegel von 14 stoffwechselgesunden Müttern nach zehnstündigem Fasten betrug 18.5 $+3.6 \mu \mathrm{E} / \mathrm{ml}$ (Mittelwert mit Standardabweichung). Der Blutinsulinspiegel ihrer Neugeborenen (Körpergewicht im Mittel $3.420 \mathrm{~kg}$, alle $<4.000 \mathrm{~kg}$ bei 38 bis 41 Schwangerschaftswochen) war sowohl in der vena umbilicalis $(5.6 \pm$ $0.7 \mu \mathrm{E} / \mathrm{ml})$ als auch in der arteria umbilicalis $(6.6+0.7$ $\mu \mathrm{E} / \mathrm{ml}$ ) niedrig. Der Plasmaglucosespiegel bei den Müttern 
betrug $99.7 \pm 3.9 \mathrm{mg} / 100 \mathrm{ml}$, in der vena umbilicalis $77.3 \pm 3.7 \mathrm{mg} / 100 \mathrm{ml}$ und in arteria umbilicalis $65.6 \pm$ $3.2 \mathrm{mg} / 100 \mathrm{ml}$, wobei sich die Werte signifikant voneinander unterscheiden. - Elf stoffwechselgesunde Mütter, die während der Geburtsperiode eine Glucoseinfusion ( $\pm 15 \mathrm{~g} / 3$ Stunden) erhielten, zeigten im Augenblick der Entbindung einen Insulinspiegel von $42.0 \pm 9.9 \mu \mathrm{E} / \mathrm{ml}$. Thre normalgewichtigen Neugeborenen (Durchschnittgewicht: $3.585 \mathrm{~kg}$; alle $<4.000 \mathrm{~kg}$ ) wiesen weder in der vena $(7.0 \pm 1.0 \mu \mathrm{E} / \mathrm{ml})$ noch in der arteria umbilicalis $(7.9 \pm 1.0 \mu \mathrm{E} / \mathrm{ml})$ eine Erhöhung des Blutinsulinspiegels auf. Die Glucosekonzentration im Plasma der Mütter beträgt $128.0 \pm 7.7 \mathrm{mg} / 100 \mathrm{ml}$, in der vena umbilicalis $105.0 \pm 7.5 \mathrm{mg} / 100 \mathrm{ml}$ und in arteria umbilicalis $88.8 \pm$ $8.6 \mathrm{mg} / 100 \mathrm{ml}$. Diese Werte unterseheiden sich signifikant voneinander. - Bei sechs ,Riesenkindern" (>4.000 kg), die von nicht behandelten während der Schwangerschaft zuckerkranken Müttern geboren. werden, war der Blutinsulinspiegel höher als beim normalen Neugeborenen. Drei dieser Kinder, deren Mütter keine Infusion erhalten hatten, zeigten in der vena umbilicalis einen Insulinspiégel von 38,42 und $13 \mu \mathrm{E} / \mathrm{mI}$, in der arteria umbili- calis von $17,34.5$ und $18 \mu \mathrm{E} / \mathrm{ml}$. Die drei übrigen Mütter erhielten eine Ghucoseinfusion. Ihre Neugeborenen hatten Insulinspiegel von 15.5, 65 und $19 \mu \mathrm{E} / \mathrm{ml}$ in der vena umbilicalis und $20,72.5$ und $14 \mu \mathrm{E} / \mathrm{ml}$ in der arteria umbilicalis. - Somit können wir schlußfolgern, daß normale Kinder bei der Geburt einen niedrigen Insulinspiegel haben, der in der arteria und vena umbilicalis gleich ist. Bei „Riesenkindern" von Müttern mit nicht behandelten Schwangerschaftdiabetes ist der Blutinsulinspiegel signifikant höher als bei normalen Kindern. Die Werte gemessen in der vena und arteria umbilicalis sind unterschiedlich. Dieser Hyperinsulinismus bestätigt die Beobachtung der Hyperplasie der Langerhans'schen Inseln bei totgeborenen Kindern diabetischer oder praediabetischer Mütter. Auf den Parallelismus zwischen fetalem Hyperinsulinismus und Geburtsübergewicht wird hingewiesen.

Key-words: Insulin levels, Blood sugar, Gestational diabetes, Birthweight, Placental weight, Umbilical blood insulin, Umbilical bloodsugar, Normal parturients, Latent diabetic parturients.
A glucose concentration in blood which declines rapidly to values below those observed in normal newborns is a major characteristic of the heavy infant of a diabetic mother. This condition is related to the hyperplasia of the islets of Langerhans (DRIScoll et al., 1960; NAYE et al., 1966) and a state of functional hyperinsulinism (BAIRD and FARQUHAR, 1962; CoRNBLATH and SchWARTz, 1966). The samel histological features of the islets of Langerhans have been shown to occur in heavy newborns of untreated mothers with latent or potential diabetes (DUBREUIr and ANDERoDIAS, 1920; MIILER, 1946; WOOLF and JACKSON, 1957; NAYE et al., 1966).

The object of this study was to measure separately the insulin content in the umbilical vein and in the artery, to ascertain if any difference could be demonstrated between the release of insulin by the pancreas in normal infants and in newborns with a heavy birthweight.

\section{Material and Methods}

Parturients: In a first group, 14 parturients were defined as normal by the following criteria: the mothers had no personal, obstetrical or family history suggestive of diabetes mellitus; they were between 16 and 37 years old; their weight was normal and their pregnancy was uncomplicated. Vaginal delivery occured spontaneously between the 38th and 41st week. The newborns weighed under $4.000 \mathrm{~kg}$ and had no respiratory distress syndrome, with an Apgar between eight and ten. The mothers were fasting for at least ten hours before delivery.

The second control group of 11 parturients met the same criteria as the first but received during delivery a glucose infusion of $15 \mathrm{~g}$ in three hundred milliliters water during three hours. The glucose infusion was also used as a vehicle for oxytocin.
The third group consisted of six mothers with gestational diabetes whose clinical symptoms are reported in Table 2.

Blood samples: All blood samples were collected in dry test-tubes containing powdered heparin in a concentration of 25 to $35 \mathrm{U}$. of heparin per $\mathrm{ml}$ of blood. Blood was taken simultaneously from the mother and the newborn. Blood collection from the mother was done from the forearm vein. If glucose was infused, care was taken to collect the sample from the opposite arm. To collect blood from the newborn a needle was introduced into one of the two umbilical arteries still pulsating and in to the umbilical vein. All three samples were collected simultaneously within 3 minutes after birth. All blood samples were immediately centrifuged and the plasma separated, freezed and stored at $-10^{\circ} \mathrm{C}$. until assayed for blood sugar and insulin.

Blood glucose was estimated by means of the Autoanalyser, using a ferricyanide method (Hoffman, 1937).

Insulin assay: The insulin levels were assayed by the double antibody radioimmunoassay technique of Morgar and Lazarow (1963). Human Insulin ${ }^{1}$, Insulin-125I and an insulin-binding reagent kit, which was supplied by the Radiochemical Centre, Amersham, England, were used. All assay operations were carried out at $4^{\circ} \mathrm{C}$. Except for the step of separating the precipitate from the supernatant, which was done in a cooled centrifuge at 3000 r.p.m. for 45 minutes, the instructions prescribed were closely followed throughout. The precipitate was washed once, and centrifuged again for 15 minutes. The radioactivity of the precipitate was counted in a Single Channel-Gamma Spectrometer (Philips). Duplicate assays were carried out on each sample and the mean value was expressed in $\mu \mathrm{U}$ of insulin per $\mathrm{ml}$ of plasma. The insulin levels observed

1 Obtained by courtesy of Dr. J. SchLIChrkRuLI, Novo Research Institute, Copenhagen-Denmark. 
in 12 normal adults (ranging in age from 25-35 years) in the morning hours, after twelve hours fasting, were $8.45 \pm 0.4 \mu \mathrm{U} / \mathrm{ml}$ (mean and S.E.M.).

\section{Results}

In fourteen normal mothers who did not receive an infusion of glucose the plasma glucose levels after ten hours fasting were $99.7 \pm 3.9 \mathrm{mg} / 100 \mathrm{ml}$ (mean and S.E.M.). In their newborns with a mean weight of $3.420 \mathrm{~kg}$ (all less than $4.000 \mathrm{~kg}$ ) the glucose levels were $77.3 \pm 3.7 \mathrm{mg} / 100 \mathrm{ml}$ in the umbilical vein and $65.5 \pm 3.2 \mathrm{mg} / 100 \mathrm{ml}$ in the umbilical artery (Table 1; controls).

The difference between the glucose levels in the mothers and in the umbilical vein was $22.4 \mathrm{mg} / 100 \mathrm{ml}$; between the glucose levels in the mother and in the umbilical artery it was $34.2 \mathrm{mg}$, and between the umbilical vein and artery was $11.8 \mathrm{mg} / 100 \mathrm{ml}$. These differences are, according to the method of variances, statistically significant $(F=9.07 ; d . f .=1 ; 13 ; p<0.01)$. The correlations of the plasma glucose between the mother and the umbilical vein, between the mother and the umbilical artery and between the umbilical vein and artery are significant at the respective levels of $p<0.02 ; p<0.05$ and $p<0.001$.
In their newborns with a mean birthweight of $3.585 \mathrm{~kg}$ (all less than $4.000 \mathrm{~kg}$ ) the glucose concentration in the umbilical vein was $105.0 \pm 7.5 \mathrm{mg} / 100 \mathrm{ml}$ and in the umbilical artery $88.8 \pm 8.6 \mathrm{mg} / 100 \mathrm{ml}$. The difference between the maternal glucose level and the umbilical vein level was $23 \mathrm{mg} / 100 \mathrm{ml}$, between the maternal glucose level and the umbilical artery $39.2 \mathrm{mg} / 100 \mathrm{ml}$ and between the umbilical vein and artery $16.2 \mathrm{mg} /$ $100 \mathrm{ml}$. These differences are, according to the method of variances, statistically significant $(<0.01)$. The correlations of the ghucose levels, between the mother and the umbilical vein, between the mother and the um. bilical artery and between the umbilical vein and artery are statistically significant at the respective levels of $p<0.05 ; p<0.05$ and $p<0.001$.

In this group of parturients who were given the infusion of glucose the insulin levels were $42.0 \pm 9.9 \mu \mathrm{U} / \mathrm{ml}$ in the mother, and $7.0 \pm 1.0 \mu \mathrm{U} / \mathrm{ml}$ in the umbilical vein and $7.9 \pm 1.0 \mu \mathrm{U} / \mathrm{ml}$ in the artery of their newborns. The difference between the insulin levels of the mother and the umbilical vein was $35 \mu \mathrm{U} / \mathrm{ml}$, and between the insulin levels of the mother and the umbilical artery was $34.1 \mu \mathrm{U} / \mathrm{ml}$. These differences are significant $(p<0.01)$. There is a significant correlation between the insulin level of the mother and the insulin level of

Table 1. Plasma glucose and insulin levels of normal mothers and their newborn infants with normal birthweight

\begin{tabular}{|c|c|c|c|c|c|c|}
\hline & \multicolumn{3}{|c|}{ Plasma glucose (mg/100 ml) } & \multicolumn{3}{|c|}{ Plasma insulin (I.M.I. : $\mu \mathrm{U} / \mathrm{m}]$ ) } \\
\hline & $\begin{array}{l}\text { Controls } \\
(n=14) \\
\text { mean } \pm \text { S.E.M. }\end{array}$ & $\begin{array}{l}\text { Infused } \\
(n=11) \\
\text { mean } \pm \text { S.E.M. }\end{array}$ & $\begin{array}{l}\text { Differences } \\
\text { (between } \\
\text { means) }\end{array}$ & $\begin{array}{l}\text { Controls } \\
(n=14) \\
\text { mean } \pm \text { S.E.M. }\end{array}$ & $\begin{array}{l}\text { Infused } \\
(n=11) \\
\text { mean } \pm \text { S.E.M. }\end{array}$ & $\begin{array}{l}\text { Differences } \\
\text { (between } \\
\text { means) }\end{array}$ \\
\hline Mother: antecubital vein & $99.7 \pm 3.9$ & $128.0 \pm 7.7$ & $28.3^{2}$ & $18.5 \pm 3.6$ & $42.0 \pm 9.9$ & $23.5^{1}$ \\
\hline Newborn: umbilical vein & $77.3 \pm 3.7$ & $105.0 \pm 7.5$ & $27.5^{2}$ & $5.6 \pm 0.7$ & $7.0 \pm 1.0$ & $1.4^{3}$ \\
\hline umbilical artery & $65.5 \pm 3.2$ & $88.8 \pm 8.6$ & $23.3^{1}$ & $6.6 \pm 0.7$ & $7.9 \pm 1.0$ & $1.3^{3}$ \\
\hline
\end{tabular}

t-test: ${ }^{1}: p<0.02 ;^{2}: p<0.002 ;{ }^{3}:$ N.S.

In the same group (Table 1 ; controls), the insulin levels of the mothers were $18.5 \pm 3.6 \mu \mathrm{U} / \mathrm{ml}$ (mean; S.E.M.) and of the newborns $5.6 \pm 0.7 \mu \mathrm{U} / \mathrm{ml}$ in the umbilical vein and $6.6 \pm 0.7 \mu \mathrm{U} / \mathrm{ml}$ in the artery. The difference between the insulin levels of the mother and of the umbilical vein was $12.9 \mu \mathrm{U} / \mathrm{ml}$ and between the insulin levels of the mother and the umbilical artery was $11.9 \mu \mathrm{U} / \mathrm{ml}$. These differences are statistically significant ( $p<0.01$ ). There is no significant difference between the insulin levels of the umbilical vein and of the artery $(1 \mu \mathrm{U} / \mathrm{ml})$. The correlation between the insulin levels of the umbilical vein and artery is statistically significant $(p<0.01)$. There is no correlation between the glucose and the insulin levels of the mother, or the insulin level of the mother and the insulin level in the umbilical vessels.

A second group of eleven normal mothers (Table 1; infused) received a glucose infusion (ca. $15 \mathrm{~g} / 3$ hours) containing small amounts of oxytocin during delivery. Their venous glucose levels were $128.0 \pm 7.7 \mathrm{mg} / 100 \mathrm{ml}$. the umbilical vein $(p<0.05)$ and the insulin level of the artery $(p<0.05)$. There is also a correlation between the glucose of the mother and the insulin level of the umbilical vein $(p<0.05)$. There is no correlation in the insulin levels of the umbilical vein and artery.

The data in these two groups of normal parturients were then compared with each other: the differences were analyzed according to the student t-test and are reported in Table 1. The glucose infusion significantly increased the glucose levels in the maternal vein, in the umbilical vein and the artery. Glucose infusion significantly increased the insulin level of the blood of the mother but not in the cord blood.

In a third group, glucose and insulin levels were recorded in mothers with untreated gestational diabetes and in their newborns with large birthweight $(>4.100 \mathrm{~kg})$. The clinical data of the mothers and their newborns are reported in Table 2, their glucose levels in Table 3, and their insulin levels in Table 4. The infant of patient no. 509 was born without arterio-venous dif- 
ference for glucose presumably due to his distress syndrome (CRAWrord, 1965). Three (no. 330, 408, 509) of the six mothers received glucose infusions of the same order as the subjects of the second group. The individual insulin levels in the umbilical vein and artery were higher than in normals and the levels in the umbilical vein and the artery were different from one another. that in the umbilical vein, and in the latter it was higher than in the artery.

When the mother was infused with glucose ${ }^{2}$ the maternal plasma glucose rose significantly as did the umbilical venous and arterial plasma glucose. The increase of the plasma glucose in the mother was of the same order of magnitude as the elevation in the glucose content of the umbilical vein and in the artery. The

Table 2. Clinical data of mothers with untreated gestational diabetes (vaginal delivery)

\begin{tabular}{|c|c|c|c|c|c|c|c|c|c|}
\hline \multirow[b]{2}{*}{ Case } & \multicolumn{4}{|c|}{ Mother } & \multicolumn{4}{|c|}{ Newborn } & \multirow{2}{*}{$\begin{array}{c}\text { Placent } \\
\begin{array}{c}\text { Weight } \\
\text { (g) }\end{array}\end{array}$} \\
\hline & $\begin{array}{l}\text { Age } \\
\text { (year) }\end{array}$ & $\begin{array}{c}\text { Weight } \\
\text { (kg) }\end{array}$ & Par./Grav. & GTT $^{1}$ & Weeks & $\begin{array}{c}\text { Weight } \\
(\mathrm{kg})\end{array}$ & Agpar & Aspect & \\
\hline No. 247 & 30 & 144 & $5 / 6$ & & 37 & 4.940 & 9 & cushingoid $^{2}$ & 860 \\
\hline No. 337 & 44 & 99 & $8 / 9$ & abnormal & 37 & 4.320 & 9 & cushingoid & 700 \\
\hline No. 340 & 35 & 99 & $1 / 2$ & abnormal & 38 & 4.030 & 10 & normal & 950 \\
\hline No. 330 & 21 & 83.5 & $1 / 2$ & abnormal & 41 & 4.600 & 8 & normal & 810 \\
\hline No. 408 & 41 & 90 & $4 / 5$ & abnormal & 38 & 4.650 & 9 & cushingoid & 1000 \\
\hline No. 509 & 37 & 140 & $3 / 5$ & abnormal & 38 & 5.140 & 5 & cushingoid & 1050 \\
\hline
\end{tabular}

1 GTT of the latent diabetic type presents at least two blood-sugar values higher than the upper limit of normal, provided that fasting levels remain below $130 \mathrm{mg} / 100 \mathrm{ml}$.

Normal GTT: values not exceeding 100, 180,140,110 and $110 \mathrm{mg} / 100 \mathrm{ml}$ at times: 0, 45, 90,135 and $180 \mathrm{minutes}$ after $100 \mathrm{~g}$ glucose loading respectively.

2 Cushingoid refers to the typical aspect of the infant of the diabetic or latent diabetic mother described by FARQUHAR (1959) and HOET et al. (1960).

Table 3. Plasma glucose levels of untreated gestational diabetic mothers and their newborn infants with large birthweight $(>4.000 \mathrm{~kg})$

\begin{tabular}{l|cll}
\hline \multirow{2}{*}{ Case } & \multicolumn{3}{|c}{ Plasma glucose (mg/100 ml) } \\
\cline { 2 - 4 } & Mother & Newborn & \\
\cline { 2 - 4 } & $\begin{array}{l}\text { Antecubital } \\
\text { vein (M.V.) }\end{array}$ & $\begin{array}{l}\text { Unbilical vein } \\
\text { (U.V.) }\end{array}$ & $\begin{array}{l}\text { Umbilical artery } \\
\text { (U.A.) }\end{array}$ \\
\hline No. 247 & 66 & 62 & 47 \\
No. 337 & 120 & 86 & 51 \\
No. 340 & 88 & 65 & 50 \\
No. 330 + & 110 & 70 & 46 \\
Glucose inf. & & & \\
No. $408+$ & 135 & 100 & 78 \\
Glucose inf. & & & \\
No. 509 + & 156 & 112 & 115 \\
Glucose inf. & &
\end{tabular}

In Fig. 1 are shown the insulin levels in the umbilical vein and in the artery in relation with the birthweight. It is noticable that the highest insulin levels occur in infants with a birthweight greater than $4.000 \mathrm{~kg}$.

\section{Discussion}

The blood supply between mother and foetus gives an opportunity to analyse the carbohydrates and the insulin that are brought to the foetus by the umbilical vein and that are returned to the placenta through the two umbilical arteries. In the group that did not receive the infusion, the glucose content of the blood in the antecubital vein of the mothers was higher than
Table 4. Plasma insulin levels of untreated gestational diabetic mothers and their newborn infants with large birthweight $(>4.000 \mathrm{~kg})$

\begin{tabular}{l|lll}
\hline \multirow{2}{*}{ Case } & \multicolumn{3}{|l}{ Plasma insulin (I.M.I. : $\mu \mathrm{U} / \mathrm{ml}$ ) } \\
\cline { 2 - 4 } & Mother & Newborn \\
\cline { 2 - 4 } & $\begin{array}{l}\text { Antecubital } \\
\text { vein (M.V.) }\end{array}$ & $\begin{array}{l}\text { Umbilical vein } \\
\text { (U.V.) }\end{array}$ & $\begin{array}{l}\text { Umbilical artery } \\
\text { (U.A.) }\end{array}$ \\
\hline No. 247 & 56 & 38 & 17 \\
No. 337 & 27 & 42 & 34.5 \\
No. 340 & 17.5 & 13 & 18.5 \\
No. $330+$ & & & \\
Glucose inf. & 85 & 15.5 & 20 \\
$\begin{array}{l}\text { No. } 408+ \\
\text { Glucose inf. }\end{array}$ & 23 & 65 & 72.5 \\
No. 509 + & & & \\
Glucose inf. & 21 & 19 & 14
\end{tabular}

gradient was similar to the one observed in the noninfused mother.

The correlation between the plasma glucose in the maternal vein, the umbilical vein and in the artery is present in the infused as in the non-infused group. CRAWFORD (1965) analyzing the slopes of the glucose concentration from the maternal artery to the umbilical

2 The same amount of oxytocin (3 units Voegtlin) used in the glucose solution was diluted and did not modify the glucose, nor the insulin levels in non-pregnant women. In partirients, saline perfusion with oxytocin (3 units Voegtlin) did not modify these two parameters. Therefore the glucose-oxytocin perfusion will be referred to as glucose perfusion. 
vein and from the umbilical vein to the artery, suggested that "the balance of the maternal-foetal glucose concentration was maintained in a minute to minute fashion, even in the face of a rapidly changing concentration of maternal blood sugar".

The mean insulin concentration at birth found in the umbilical vein of a normal foetus from a non-in-

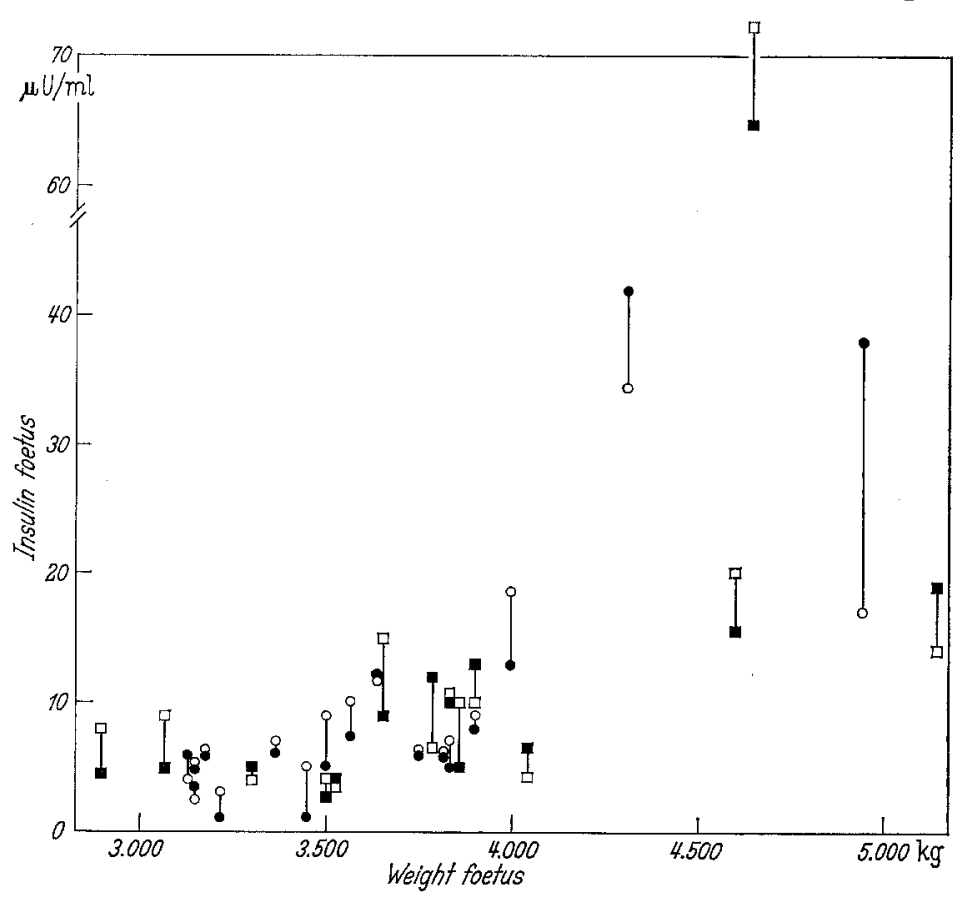

Fig. 1. Relation between birthweight of the foetus and the insulin levels in the umbilical vessel - Umbilical vein, 0 umbilical artery = Newborns of mothers without glucose infusion; Umbilical vein, $\square$ umbilical artery $=$ Newborns of mothers with glucose infusion.

fused, normal mother was $5.6 \pm 0.7 \mu \mathrm{U} / \mathrm{ml}$, which compares well with $9.0 \pm 1.0 \mu \mathrm{U} / \mathrm{ml}$ observed by MILNER and HALES (1965) under the same conditions, and with $5.93 \pm 0.64 \mu \mathrm{U} / \mathrm{ml}$ reported by DITSCHUNEIT et al. (1966); but it is different from that reported by SPELlacy et al. (1964), who found $42 \mu \mathrm{U} / \mathrm{ml}$. Our levels in the umbilical vein are significantly lower than the fasting level of normal adults $(8.45 \pm 0.4 \mu \mathrm{U} / \mathrm{ml})$. The changes of the insulin levels that occur during infusion did not parallel the modifications of the glucose levels. The difference in the insulin level between the venous blood of non-infused mothers and the umbilical vein blood was $12.9 \mu \mathrm{U} / \mathrm{ml}$, and it was the same for the umbilical artery. For the infused parturients this difference between the mother and the umbilical vein was $35 \mu \mathrm{U} / \mathrm{ml}$ and remained the same for the umbilical artery.

In the non-infused mother, the ratio of the maternal insulin level to the insulin level in the umbilical cord was three to one, and during glucose infusion this ratio was six to one. The difference in the ratio is due to the increase in the insulin level of the mother and to the constancy of the foetal insulin level in both groups. Newborns with normal birthweight and normal placental weight maintained similar insulin levels in the umbilical vein and in the artery. The glucose-insulin homeostatis in the foeto-placental unit seems to be a stable one, which is not easily changed by the supply of glucose readily offered by placental passage from the mother to the foetus.

The foetal pancreas appears to be less sensitive to the glucose stimulation than the mother's pancreas, as an increase of $27 \mathrm{mg} / 100 \mathrm{ml}$ in glucose concentration in the mother elevated the insulin level in the mother, whereas the glucose addition in the foetus did not modify the foetal insulin level. Previous authors have already suggested that the pancreas of the normal newborn did not react briskly to glucose. BATRD and FARQUHAR (1962) demonstrated this by administering glucose through the umbilical vein, and MrLner and Hales (1965) observed a slow maximal insulin increase in umbilical vein blood when glucose was injected in the mother during parturition. These latter authors included in their normal infants newborns whose birthweight went up to $4.500 \mathrm{~kg}$, who may be responsible for the statistical increase of the insulin levels.

It appears that the glucose-insulin homeostasis of the normal foeto-placental unit relies completely on the flexible and rapidly changing glucose-insulin equilibrium in the mother.

The normal ratio of insulin levels between mother and foetus was no longer observed when the mother presented untreated gestational diabetes. The insulin levels observed in the umbilical vein and artery of heavy weight newborns were higher than the levels observed in normal infants. Both BAIRD and FARQUHAR (1962) using a biological assay and Jorgersen et al. (1966) using a radioimmunological method have observed in overweight newborns from treated diabetic mothers a brisk, immediate insulin response to glucose administration. Their pancreas seems to have been sensitized to glucose during their foetal life. A similar functional hyperinsulinism to account for the rapid fall of blood sugar concentration immediately after birth has been postulated in children born from mothers with gestational diabetes (CORNBLATH and SCHWARTz, 1966).

A correlation between high insulin levels in total cord blood and the excessive birthweight is recorded by Ditschuneit et al. (1966) and SHIMA et al. (1966), but these authors did not investigate separately the umbilical vein and artery. HeLwig (1940) and CARDELC (1953) previously reported a direct correlation between the mean surface area of the islets of Langerhans and the birthweight of infants from treated diabetic women. In addition, our results show a difference between the insulin content of the umbilical vein and 
the artery, but this difference, which did not exist in normal infants, was not always in the same direction; the levels in the vein were sometimes higher than in the artery and vice versa. These results suggest that factors which maintain the constancy of the insulin levels in the foeto-placental unit are modified in these cases.

It is apparent from our data that the stable glucoseinsulin homeostasis observed in the normal infant has changed in these heavy birthweight infants born from untreated mothers with gestational diabetes to an unpredictable glucose-insulin relationship.

Acknowledgements. The authors wish to express their appreciation for the excellent technical assistance of Miss B. Hormmans and their thanks for the active collaboration of Prof. J. Floris and M.E. Meulepas, University Calculation Centre, Louvain.

We are indebted to Dr. E. Ross, University College Hospital Medical School, University of London for reviewing the manuscript.

\section{References}

BATRD, J.D., and J.W. FARQUHAR: Insulin-secreting capacity in newborn infants of normal and diabetic wo men. Lancet $1962 \mathrm{I}, 71-74$.

CARDELL, B.S.: Hypertrophy and hyperplasia of the pancreatic islets in newborn infants. J. Path. Bact. 66, $335-346$ (1953).

CoRnblath, M., and R. Schwartz: Disorders of carbohydrate metabolism in infancy. Vol. III in the Series: Major problems in clinical pediatrics, Saunders, 1966.

CRAwFORD, J.S.: Maternal and cord blood at delivery. IV. Glucose, Sodium, Potassium, Calcium and Chloride. Biol. Neonat. 8, 222-237 (1965).

Ditschuneit, H., D. Griebner, M. Macht, J. Ammon und E.F. Pfeiffere: Vergleichende Untersuchungen über Insulinaktivitäten im Blut von Neugeborenen von Stoffwechselgesunden, prädiabetischen Müttern und ihre Beeinflussung durch I.V. Glucosebelastung. II. Annual Meeting of the European Association for the Study of Diabetes, Aarhus, 1966.

Driscoly, S.G., K. Bernirschke and G.W. Curtis: Neonatal deaths among infants of diabetic mothers:
Post-mortem findings in ninety-five infants. Amer. J. Dis. Child. 100, 818-835 (1960).

Dubreuil, G., et ANDERodias : Ilots de Langerhans géants chez un nouveau-né issu de mère glycosurique. C. R. Soc. Biol. 73, 1490-1493 (1920).

FarquHAR, J.W.: The child of the diabetic women. Arch. Dis. Child. 34, 76-96 (1959).

HeiwiG, E.B.: Hypertrophy and Hyperplasia in Islets of Langerhans in infants born of diabetic mothers. Arch. intern. Med., 65, $221-239$ (1940).

Hoet, J.P., A. Gommers and J.J. Howt : Causes of congenital malformations: role of prediabetes and hypothyroidism in Ciba Foundation Symposium on congenital malformations. p. 219-235. London: Churchill 1960.

Hoffman, W.S.: A rapid photoelectric method for the determination of glucose in blood and urine. J. biol. Chem. 120, 51-55 (1937).

Jorgensen, K.R., T. Deckert, L.M. Pedersen and J. Pedersen: Insulin, insulinantibody and glucose in plasma of newborn infants of diabetic women. Acta Endocr. 52, 154-167 (1966).

MrLLER, H.C.: The effect of diabetic and prediabetic pregnancies on the foetus and the newborn infant. $J$. Pediat. 29, 455-461 (1946).

MrLNER, R.D.G., and C.N. HALEs : Effect of intravenous glucose on concentration of insulin in maternal and umbilical cord plasma. Brit. med. J. 1965 I, 284-286.

MoRgaN, G.R., and A. Lazarow: Immunoassay of insulin: Two antibody system. Plasma insulin levels of normal, subdiabetic and diabetic rats. Diabetes 12, $115-126$ (1963).

NAYE, R.L., E.A.H. Sims, G.W. Wetsh and J. GRaX: Newborn organ abnormalities. Arch. Path. 81, 552$557(1966)$.

Spellacy, W.N., F.C. Goetz, B.Z. GreenberG and J. EuLs: The human placental gradient for plasma insulin and blood glucose. Amer. J. Obstet. Gynec. 90, 753757 (1964).

ShIMA, K., S. Price and P.P. FoA: Serum insulin concentration and birthweight in human infants. Proc. Soc. exp. Biol. (N.Y.) 121, 55- 59 (1966).

WoOLF, N., and W.P.U. JACkson: Maternal prediabetes and the foetal pancreas, J. Path. Bact. 74, 223-226 (1957).

Dr. Joseph J. Hoet,

Laboratoire de Recherches de la Clinique Médicale, Hôpital Saint Pierre, Université de Louvain, Louvain, Belgique 